\title{
Solar Energy for Process Heating: a Case Study of Select Indian Industries
}

\author{
Suresh N S* and Badri S Rao
}

Center for Study of Science Technology and Policy, No. 18\&19, 10th Cross, Papanna Layout, Mayura Street, Nagashettyhalli, RMV II stage, Bengaluru-560 094, Karnataka, India

\begin{abstract}
The annual consumption of petroleum products in India was about 221 million metric tons in 2015 . Of this, $84 \%$ was imported. The Indian industrial sector accounts for about $16 \%-20 \%$ of the total fuel consumption for thermal energy for different heating applications in the temperature range of $50^{\circ} \mathrm{C}-250^{\circ} \mathrm{C}$. Solar collectors can meet these temperature requirements and offer the possibility to mitigate the consumption of oil. This study highlights the fact that conversion efficiency from solar energy is much higher for process heating than for electricity generation and that process heating applications constitute a significant share of industrial energy consumption. In this paper, a methodology has been developed to estimate the potential for integration of solar collectors for process heating. The methodology employs process operating temperatures to select the type of solar collectors. The size of the solar field is estimated taking into account the thermal heat loads, working fluid and temperatures of these processes, the efficiency of the chosen solar collectors, location-based solar irradiance and capacity utilization of the solar collectors. The proposed methodology has been validated with a software tool called System Advisor Model (SAM). The techno-economic analysis will indicate the viability of solar systems for integration in industries. Therefore, the consociated parameters on economic (capital cost, fuel oil savings, monetary benefits), financial (Payback periods, Rates of Returns) and environmental (Carbon savings) are estimated. Further, the methodology has been applied to select Indian industries to verify its potential quantitatively. The industries selected include Textile, Pulp \& Paper, Dairy, Leather and Automobile. Processwise energy demands are considered while estimating the potential as the fuel requirement offset by solar energy in terms of absolute fuel oil savings, monetary benefits and carbon savings. The other economic and financial parameters mentioned above were estimated to verify the capability and present the market position of solar systems. Further, sensitivity analyses have been performed with respect to solar energy penetration and fuel oil prices to address the viability of integration of solar energy for process heating.
\end{abstract}




\section{Nomenclature}

\begin{tabular}{|c|c|c|}
\hline Symbol & Variable Name & Units \\
\hline$A_{c}$ & Area of a solar collector & $\mathrm{m}^{2}$ \\
\hline$A_{\text {process }}$ & Solar collector area required for a process & $\mathrm{m}^{2}$ \\
\hline$C_{f}$ & Fuel oil equivalent carbon dioxide emission factor & $\mathrm{kg} /$ ton of fuel oil \\
\hline$C_{p}$ & Specific heat of working fluid & $\mathrm{kJ} / \mathrm{kg} / \mathrm{K}$ \\
\hline$I_{\text {day }}$ & Solar irradiance over the day & $\mathrm{kWh} / \mathrm{m}^{2} /$ day \\
\hline$k_{f}$ & Fuel oil equivalent energy factor & GJ/ton \\
\hline Ns & Number of sunshine days in a year & Days \\
\hline$P$ & Hot water/air requirement & Liters/ton of product \\
\hline$P_{c}$ & Solar collector system capacity & Liters per day \\
\hline$Q_{c}$ & Thermal energy collected by a solar collector over a day & $\mathrm{kJ} / \mathrm{m}^{2} /$ day \\
\hline$Q_{\text {process }}$ & Thermal energy requirement of an industry & $\mathrm{kJ} / \mathrm{year}$ \\
\hline$Q_{\text {thermal }}$ & Thermal energy supplied by a solar collector over a year & GJ/year \\
\hline$Q_{y e a r}$ & Thermal energy collected by a solar collector over a year & $\mathrm{kJ} / \mathrm{m}^{2} /$ year \\
\hline$T_{a}$ & Ambient temperature & ${ }^{\circ} \mathrm{C}$ \\
\hline$T_{\text {avg }}$ & Average temperature of fluid in a process & ${ }^{\circ} \mathrm{C}$ \\
\hline$T_{\text {in }}$ & Inlet temperature of fluid in a process & ${ }^{\circ} \mathrm{C}$ \\
\hline$T_{\text {out }}$ & Outlet temperature of fluid in a process & ${ }^{\circ} \mathrm{C}$ \\
\hline$q_{\text {process }}$ & Thermal energy requirement of a process & $\mathrm{kJ} /$ ton of product \\
\hline$t_{f}$ & Tilt factor & Constant \\
\hline$Y_{p}$ & Production capacity of the industry & Tons/year \\
\hline$D P P$ & Discounted payback period & Years \\
\hline$I R R$ & Internal Rate of Return & $\%$ \\
\hline$\eta$ & Efficiency of solar collectors & $\%$ \\
\hline$\eta_{\text {combustion }}$ & Combustion efficiency & $\%$ \\
\hline
\end{tabular}

Abbreviations: DNI, Direct Normal Irradiation; ETC, Evacuated Tube Collector; FPC, Flat-Plate Collector; GHI, Global Horizontal Irradiation; HTC, High-Temperature Collector; IEA, International Energy Agency; IREDA, Indian Renewable Energy Development Agency Ltd.; LTC, Low-Temperature Collector; MTC, Medium Temperature Collector; NDCs, Nationally Determined Contributions; NREL, National Renewable Energy Laboratory; RE, Renewable Energy; SAM, System Advisor Model. 


\section{Introduction}

The socioeconomic growth of a country depends a lot on the availability of energy (Adams et al., 2016; Kanagawa and Nakata, 2007). The source of this energy is a critical parameter to be evaluated with respect to energy security, sustainability and its impact on the environment (Dawn et al., 2016). As an example, the total installed capacity of electricity in India is $306 \mathrm{GW}$, of which $70 \%$ is derived from fossil fuels, $15 \%$ from nuclear and hydro, and 15\% from Renewable Energy (RE) sources (CEA, 2016), with a small contribution from clean energy sources. Further, $85 \%$ of the crude oil requirement in India is met through imports. According to International Energy Agency (IEA), these imports will increase to 91.6\% by 2020 (Mauthner and Werner, 2014). India spent about US\$ 6711 million annually on oil imports from 1957 to 2016. The expenditure reached an all-time high of US\$ 45,281.9 million in May 2011, with an average of about US\$ 25,000 million per month only in the past decade (Trading Economics, 2016). At the same time, the Prime Minister of India recently announced the government's intention to reduce dependence on oil imports by $10 \%$ by 2022 and $50 \%$ by 2030 (Sudheer, 2015). India's emissions presently exceed $2.5 \mathrm{Gt}$ of $\mathrm{CO}_{2}$, which is $6.5 \%$ of the total world emissions (Liu, 2016). In an effort to check these emissions, the government has taken many initiatives to reduce the national carbon footprint as reflected in the National Action Plan on Climate Change, the Nationally Determined Contributions (NDCs), The International Solar Alliance and RE goals. These initiatives are mainly to mainstream alternate clean energy sources and increase the energy efficiency of existing technologies to address the rising demand for energy, issue of climate change, energy security, reduce oil import dependence, etc. India aims to achieve the following RE targets by 2022: $100 \mathrm{GW}$ from solar, $60 \mathrm{GW}$ from wind, $10 \mathrm{GW}$ from biomass and $5 \mathrm{GW}$ from small hydro. In addition, India's NDC goal is to achieve $40 \%$ of total installed power generation capacity from RE and reduce the emission intensity per GDP unit to 33\%-35\% below the 2005 levels by 2030 (Ashok, 2015). In this context, the present study has been conducted to develop a methodology for assessing the potential of solar energy for process heating in any industry. Further, a case study has been presented for select industries in India to assess the techno-economic potential quantitatively.

Fossil fuels currently play a significant role in fulfilling the demand for process heating in industries for various applications. A majority of these processes operate in the temperature range of $50^{\circ} \mathrm{C}-250^{\circ} \mathrm{C}$ (Fuller, 2011; Kalogirou, 2003). In India, these processes generate oil consumption of about 40\% (70 Million Metric Tons) of the total oil consumption of the country (EIA, 2013; MPNG, 2015; Rastogi, 2014). The use of solar collectors as an alternative for supplying this heat can reduce the usage of fossil fuels to some extent. At present, most of the solar collectors are used for domestic water heating. For use in industries for processes like sterilization, pasteurization, drying, evaporation, washing, cleaning, bleaching, cooking, pre-heating, etc. (ETSAP and IRENA, 2015), solar collectors will have to supply heat in the required temperature ranges for specific processes.

The integration of solar collectors in existing process cycles is, however, a challenging task. Also, some industrial processes operate round the clock and require constant energy continuously. Despite the potential of solar collectors in meeting the required heat demand, their smooth operation is a challenge owing to the intermittent nature of solar irradiance. Further, since sunlight is available for only one-third of a day, storage or hybridization would be required (Kulkarni et al., 2008). Though a system containing solar with storage and hybridization (with fuel source such as natural gas or fuel oil) is an option to avoid process intermittency, this would generate additional costs. The working fluid must be pressurized if required temperatures are above $100^{\circ} \mathrm{C}$ for heating applications to avoid boiling (in case of water) inside the solar collector system.

According to a report released by the IEA (Mekhilef et al., 2011), solar energy will be able to meet about $45 \%$ of the global energy demand by 2050. Many strategic programs are already underway across the globe to increase its adoption (ESTTP, 2008; MNRE, 2010; SERIIUS, 2016).

A brief summary of the literature findings on solar energy for process heating is covered in this paragraph. (Carnevale et al., 2011) analyzed the impact of integration of parabolic trough solar systems in a Textile factory both technically and economically. They found that although integration leads to annual natural gas savings of $40 \%-50 \%$ (out of $47 \mathrm{Nm}^{3}$ ), it is not sufficient to recover the capital investment. However, a decrease of $50 \%$ in the cost of solar components reduces the payback period to 6 years. (Fuller, 2011) reviewed the achievements of solar industrial process heating in Australia and found that solar-based systems are technically feasible but not viable financially (payback period is more than 17 years) due to high capital cost. (Silva et al., 2014) studied the thermo-economics of a solar plant for industrial process heating and found that solar energy will play a vital role if fossil fuel prices increase rapidly. (Koroneos and Nanaki, 2012) examined the life-cycle assessment of a solar water heater and found that a $4 \mathrm{~m}^{2}$ flat-plate collector (FPC) can provide energy of $1,700 \mathrm{kWh} / \mathrm{year}$ and monetary life-cycle savings of US\$5,600 with a payback period of 5 years. 
The available literature is not sufficient if one is interested to verify the possibility of integration of solar thermal collectors for process heating in industries and its potential at national level. Therefore, the current study proposes a methodology to estimate the potential of solar energy collectors for process heating in industries. Further, this methodology is applied to select Indian industries, as a case study, to understand the gross potential of solar thermal collectors. The unique feature of this paper is that it considers the process-wise energy demand in industries while estimating the potential at national level. The gross assessment is expressed in terms of economic and environmental benefits. Sensitivity analyses are performed to observe the impact of fuel oil price and solar energy penetration rate on key economic parameters. Details of the methodology and potential findings from select Indian industries are explained in the following sections.

\section{Methodology}

A methodology has been developed to estimate the potential of solar energy for process heating in industries. Initially, all processes in each industry that requires thermal energy are identified. The operating temperatures of these processes are considered for the selection criteria for solar collectors. Further, the total quantum of thermal energy required for each industry is estimated based on the production capacity of the industry at national level. This total thermal energy is used to estimate the size of the solar field required for each industry. The associated capital costs and payback periods for retrofitting solar collectors are then estimated. Benefits in terms of $\mathrm{CO}_{2}$ reductions and monetary are also quantified with offsetting of base-fuel. These economic and environmental parameters are useful in addressing the sustainability aspects of this intervention. The method for integrating a solar thermal collector for process heating is shown in Fig. 1.

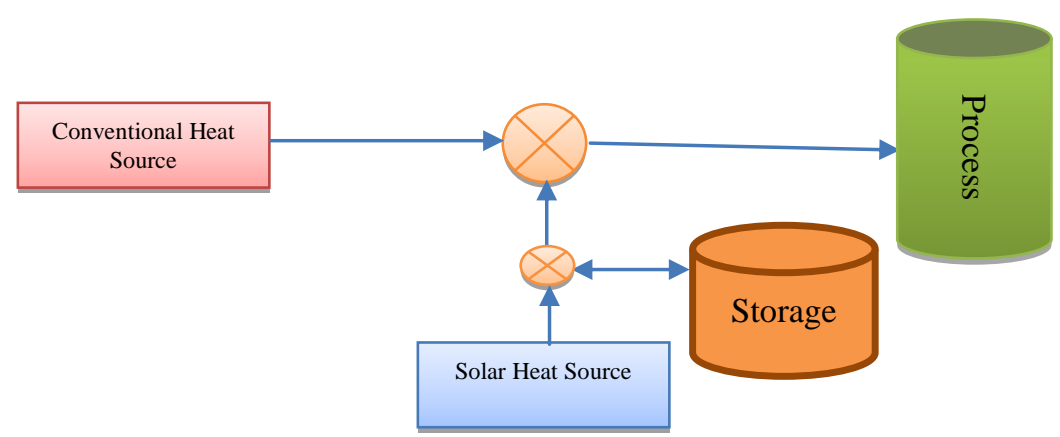

Fig. 1: Method for integrating a solar thermal collector for process heating

The sections below describe the detailed step-by-step methodology used to carry out the potential assessment.

\subsection{Selection of Solar Collectors for Process Heating}

Solar collectors can be primarily categorized as low- (LTCs), medium- (MTCs) and high-temperature collectors (HTCs) with operating temperatures of $<80^{\circ} \mathrm{C}, 80^{\circ} \mathrm{C}-250^{\circ} \mathrm{C}$, and $>250^{\circ} \mathrm{C}$, respectively (Tchanche, 2015). LTCs are mainly used for water heating and space heating applications. MTCs are used for generating hot water, steam and hot air in industrial process heating and cooling applications, whereas an HTC is mainly used for power generation and for supplying hot water/steam. Most of the LTCs and MTCs are stationary-type collectors and they do not track the sun, whereas HTCs are moving-type collectors and track the position of the sun over a day. An appropriate combination of these types can be used in different industries depending on the heat demand in different processes.

The selection of a solar collector depends on the operating temperatures of the processes. Most of the industrial processes require thermal heating at temperatures in the range of $40^{\circ} \mathrm{C}-250^{\circ} \mathrm{C}$ (Fernández-García et al., 2015; Kalogirou, 2003; Schnitzer et al., 2007). FPCs and Evacuated Tube Collectors (ETCs) are economical to generate heat up to $150^{\circ} \mathrm{C}$ for process heating (Kalogirou, 2004). HTCs can generate heat up to $400^{\circ} \mathrm{C}$, but the interventions for process heating in industries are capital- and space-intensive. In addition, HTC technologies such as parabolic trough, linear Fresnel and Solar Tower are not suitable for industrial wastelands (Purohit et al., 2013). Therefore, dish collectors are considered among other HTC technologies for processes that can generate temperatures greater than $150^{\circ} \mathrm{C}$. Water and air are appropriate working fluids in these collectors. Forcedcirculation solar collectors are preferable for industrial purposes. ETCs are suitable for use in cold climate as they have no freezing issues. However, ETC-type collectors are made of glass and are fragile in nature, whereas FPCs contain metallic components and have longer lives. Dish collectors require high capital investment 
compared with FPCs and ETCs, but they can generate higher temperatures. The general plant life for an FPC, an ETC and a Dish are 20,15 and 25 years, respectively. Table 1 mentions the criteria for selecting the type of solar collector based on the average operating temperatures of industrial processes.

Table 1: Selection of Solar Collector based on the Operating Temperature of a Process

\begin{tabular}{ccc}
\hline $\begin{array}{c}\text { Operating } \\
\text { temperature }\left(\boldsymbol{T}_{\boldsymbol{a v g}}\right),{ }^{\mathbf{o}} \mathbf{C}\end{array}$ & Solar collector & $\begin{array}{c}\text { Lifetime } \\
\text { (years) }\end{array}$ \\
\hline $40-80$ & Flat-plate & 20 \\
$80-150$ & Evacuated tube & 15 \\
$>150$ & Dish & 25 (glass based) \\
\hline
\end{tabular}

\subsection{Input Parameters for the Methodology}

The inputs for the techno-economic assessment of solar collectors are as follows:

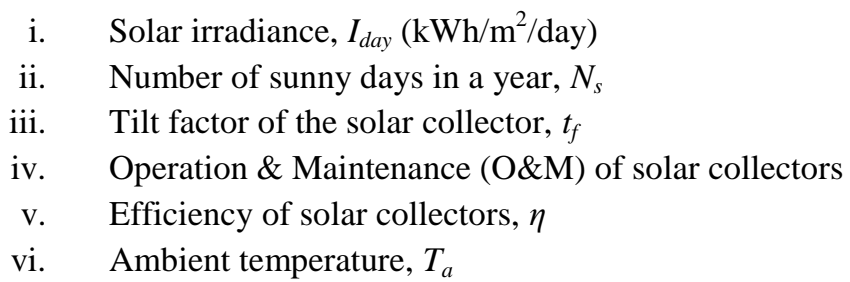

\subsection{Estimation of Thermal Energy Requirement}

The steps followed for estimating the thermal energy requirement in any industry are given below:

1. Identify the number of processes required for thermal heating

2. Calculate the average operating temperature for each process, $T_{\text {avg }}\left({ }^{\circ} \mathrm{C}\right)$

3. Calculate the hot water/hot air requirement for each process, $P$, as liters/ton of product

4. Estimate the thermal energy requirement (heat demand), $q_{\text {process }}$, as $\mathrm{kJ} /$ ton of product (MA Ramaswamy et al., 2012):

$$
q_{\text {process }}=P \times C_{p} \times\left(T_{\text {avg }}-T_{\text {in }}\right)
$$

where $C_{p}$ is the specific heat of water or air $(\mathrm{kJ} / \mathrm{kg} / \mathrm{K})$ and $T_{i n}$ is the fluid inlet temperature.

\subsection{Estimation of the Energy and Solar Collector Area Requirements for a Specific Process}

The solar collector area is estimated based on the thermal energy requirement of a specific industrial process. The steps followed to estimate the solar collector area are shown in the flowchart in Fig. 2. The tilt factor indicated in Fig. 2 is used to adjust the solar collector such that it receives maximum amount of solar energy over the year. Tilting up a collector by an angle equivalent to latitude from horizontal (facing south for locations in Northern hemisphere and facing north in Southern hemisphere) will increase the incident irradiance compared to that of a collector which is at horizontal. This adjustment factor is called the tilt factor. Tilt is not required for tracking systems (e.g., a dish). 
Choose the requirement of hot water or hot
air for the process, $P_{c}$ (LPD) \& its operating

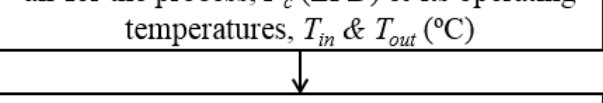

Calculate the energy generation by the chosen collector, $q_{c}=P_{c} \times C_{p} \times\left(T_{\text {out }}-T_{\text {in }}\right) \mathrm{kJ} /$ day
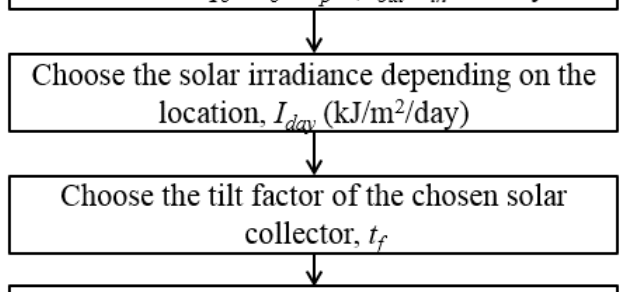

Estimate the efficiency of the solar collector using Fig. $3, n$

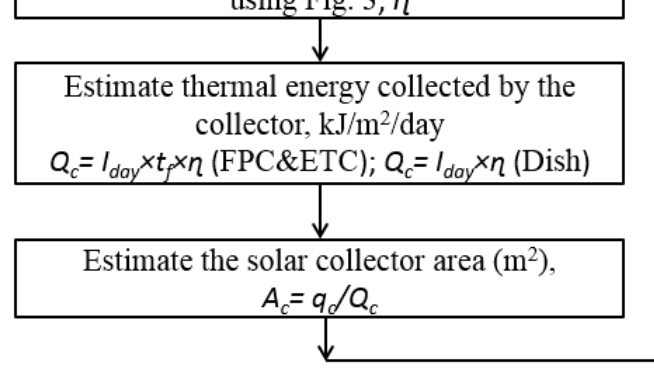

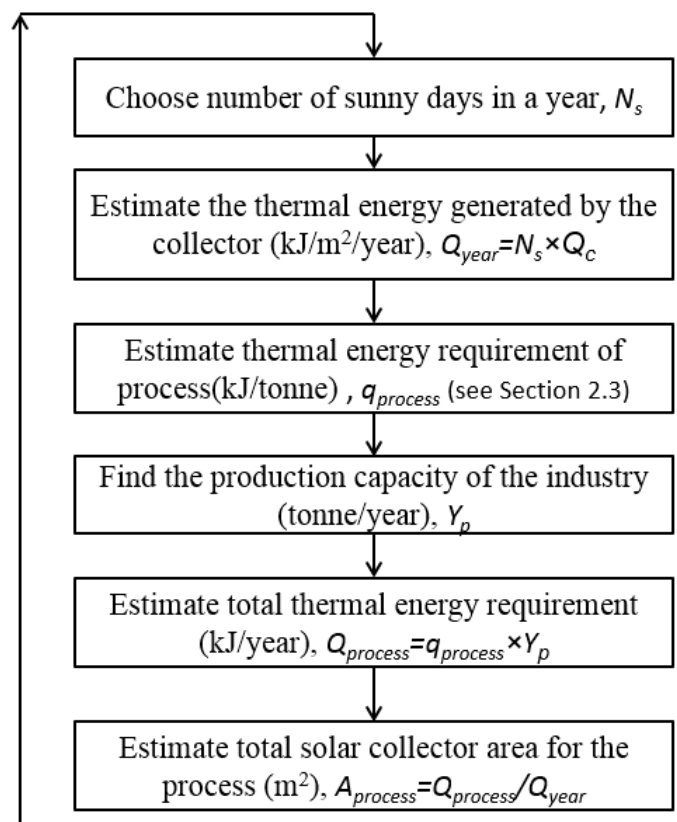

Estimate total solar collector area for the

Fig. 2: Flowchart to Estimate the Energy and Solar Collector Area Requirements for Process Heating

\subsection{Estimation of Total Capital Cost}

The steps followed for estimating the capital cost of solar collectors used for process heating in industries are as follows:

1. Identify the number of processes requiring thermal energy

2. Estimate the solar collector area required for each process as explained in Section 2.4

3. Estimate the capital cost of the solar collectors on a per $\mathrm{m}^{2}$ basis.

\subsection{Estimation of Benefits}

The benefits of the implementation of solar collectors in terms of fuel savings, monetary savings and carbon emission savings in each industry are estimated as explained below.

\subsubsection{Annual Fuel Oil Savings}

Annul fuel savings are estimated based on the amount of thermal energy ( $Q_{\text {thermal }}$ in GJ) supplied by solar collectors as follows (Karbuz, 2004):

$$
\text { Fuel oil savings (toe })=Q_{\text {thermal }} /\left(k_{f} \times \eta_{\text {combustion }}\right),
$$

where $\eta_{\text {combustion }}$ is the combustion efficiency and $k_{f}$ is the fuel equivalent energy factor in GJ per ton (e.g., $k_{f}$ for fuel oil is $41.868 \mathrm{GJ})$.

\subsubsection{Annual Net Monetary Savings}

The annual net monetary savings from the solar collectors are estimated as follows:

Net monetary savings $=($ Price of fuel oil $\times$ Fuel oil savings-Annual O\&M cost of solar collectors $)$. 


\subsubsection{Discounted Payback Period}

Discounted Payback Period (DPP) is defined as the length of time that elapses before the present value of the cumulative net cash flow first exceeds the initial cash outlay (Weil and Maher, 2005). This indicator is used to evaluate the time period required for solar collectors to recoup the capital investment and bring in profits post the payback period. DPP is estimated as follows (Weil and Maher, 2005):

$$
\text { Discounted Payback Period }=A+B / C \text {, }
$$

where $A=$ Last time period in which the cumulated cash flow was negative, year

$B=$ Absolute discounted cash flow corresponding to the year ' $A$ '

$C=$ Discounted cash flow corresponding the subsequent year (' $A+1$ ').

\subsubsection{Internal Rate of Return}

Internal Rate of Return (IRR) is a decision-making parameter that is used to calculate the rates of returns on an investment. This is estimated considering all discounted cash flows of the system over the lifetime of a project (in this case, solar collector system) using the in-built formula of Microsoft Excel, version 2013 (MA Ramaswamy et al., 2012):

$$
\text { Internal Rate of Return }=\text { IRR (all cash flows over the lifetime }) \text {. }
$$

\subsubsection{Carbon Savings}

Carbon dioxide savings due to reduction of fuel oil use for process heating are estimated as follows (Carbon Trust, 2016):

$$
\text { Annual } \mathrm{CO}_{2} \text { Savings }\left(\mathrm{kgCO}_{2}\right)=\mathrm{C}_{f} \times \text { Fuel oil savings (toe). }
$$

Here $C_{f}$ is the fuel equivalent carbon dioxide emission factor in $\mathrm{kg}$ per ton of fuel [e.g., $C_{f}$ for fuel oil is $3,232.7$ $\mathrm{kg}$ of carbon dioxide (Mauthner and Werner, 2014)].

\section{Case Study of Select Indian Industries}

The methodology presented above (Section 2) is applied to a few energy-intensive industries in India to assess the economic and environmental parameters. These parameters give an idea of the sustainability of integrating solar thermal systems for process heating in industries.

\subsection{Inputs for the Case Study}

India-specific inputs and assumptions for the case study are presented in the following section.

\subsubsection{Efficiency of Solar Collectors}

The variation of the thermal efficiencies of FPCs, ETCs and Dish solar collectors with the operating temperature of the working fluid is shown in Fig. 3 (Kedare et al., 2012; Purohit et al., 2013). $T_{o p}$ and $T_{a}$ represent the operating and ambient temperature, respectively. An increase in temperature causes more heat losses and, hence, a decrease in efficiency. The efficiencies of the collectors vary among systems according to design specifications (Kalogirou, 1999; Kedare et al., 2012). However, the variation of efficiency shown in Fig. 3 is employed for assessing solar collectors. 


\subsubsection{Assumptions}

The assumptions for the techno-economic assessment of solar collectors are as follows:

i. Global Horizontal Irradiation (GHI) and Direct Normal Irradiation (DNI) for India vary from 4.5 to 6.5 $\mathrm{kWh} / \mathrm{m}^{2} /$ day (NREL, 2015). Therefore, an average value of $5.5 \mathrm{kWh} / \mathrm{m}^{2} /$ day is taken as the reference solar irradiance.

ii. The number of sunny days $\left(N_{s}\right)$ in a year is 260 (Khare et al., 2013).

iii. The tilt factor $\left(t_{f}\right)$ of both FPCs and ETCs is taken as 1.1. See Section 2.4 for details.

iv. Solar energy penetration can technically go up to $100 \%$ with additional storage. The solar collector area will increase proportionately with the storage capacity. However, industries may have the potential of $20 \%-40 \%$ solar energy penetration (The base case study considers $20 \%$ of thermal energy demand of a process by solar energy.) Reasons for this assumption are as follows: (a) sunlight will be available for only a maximum of 10-12 hours a day; (b) most industrial processes require energy round the clock-100\% energy from solar without storage is not possible; and (c) industries have space constraints.

v. O\&M is taken as $2 \%$ of capital cost. Further, a $2 \%$ escalation is considered each year (UNDP, 2010).

vi. The thermal energy needs of the industries are predominantly met with fuel oil compared with coal and electricity (Kalogirou, 1999; Thiruchelvam et al., 2003).

vii. The efficiency of solar collectors depends on ambient temperatures. Based on the temperature variations across India, an average ambient temperature $\left(T_{a}\right)$ of $25^{\circ} \mathrm{C}$ is considered for the analysis.

viii. The percentage consumption of petroleum products in Industries is estimated based on 2012 levels.

ix. The capital costs (in US $\$ / \mathrm{m}^{2}$ ) of FPCs, ETCs and Dish collectors are 178, 163 and 331, respectively.

x. The price of fuel oil over the past decade varied from US\$1.0 to US\$3.7 per gallon (Indexmundi,

2016). This range is considered in performing the economic analysis.

\subsubsection{Validation of the methodology}

The methodology presented in Section 2 has been validated with both simulation software and experimental data. System Advisor Model (SAM), a performance and financial tool developed by National Renewable Energy Laboratory (NREL), is used as simulation software for this validation. The input parameters considered and output parameters estimated are presented in Table 2. It can be seen that the annual thermal energy generated per $\mathrm{m}^{2}$ of solar collector area matches well between the model and simulation software, with the error difference being $2.1 \%$. With respect to experimental validation, we have used the data from the demonstration system installed by the company CONTANK in Barcelona, Spain. CONTANK's system uses $510 \mathrm{~m}^{2}$ of FPC and it generated annual thermal energy of $429 \mathrm{MWh}_{\mathrm{t}}$, equivalent to $841 \mathrm{kWh} / \mathrm{m}^{2}$. Hence, the results obtained from the model are quite satisfactory to estimate the potential in process heating. 
Table 2: Validation of the methodology with SAM

\begin{tabular}{|c|c|c|}
\hline & Model & SAM \\
\hline \multicolumn{3}{|l|}{ Input parameters } \\
\hline System capacity (liters per day, LPD) & 200 & 200 \\
\hline Ambient temperature $T_{a}\left({ }^{\circ} \mathrm{C}\right)$ & 25 & 25 \\
\hline Working fluid & Water & Water \\
\hline Solar collector & FPC & FPC \\
\hline Working fluid inlet temperature $\left(T_{i n},{ }^{\circ} \mathrm{C}\right)$ & 25 & 25 \\
\hline Working fluid outlet temperature $\left(T_{\text {out }},{ }^{\circ} \mathrm{C}\right)$ & 60 & 60 \\
\hline Location & India (general) & $\begin{array}{c}\text { Ahmedabad, } \\
\text { India }\end{array}$ \\
\hline Solar collector area & 2.46 & 4 \\
\hline Solar irradiance $\left(\mathrm{kWh} / \mathrm{m}^{2} /\right.$ day $)$ & 5.5 & 5.45 \\
\hline Solar radiation availability (based on days in a year or hourly) & 260 & Hourly data \\
\hline \multicolumn{3}{|l|}{ Output parameters } \\
\hline Average collector efficiency & 0.57 & 0.55 \\
\hline Annual thermal energy generated $\left(\mathrm{kWh}_{\mathrm{t}}\right)$ & 2116.2 & 3369.4 \\
\hline $\begin{array}{l}\text { Annual thermal energy generated per unit collector area } \\
\left(\mathrm{kWh} / \mathrm{m}^{2} / \text { year }\right)\end{array}$ & 842.4 & 860.2 \\
\hline
\end{tabular}

\subsubsection{Limitations and Implications}

The present study has not included the following in its analysis:

a) Operational issues

b) Control and technical issues with resource intermittency

c) Additional costs due to water quality and flow pressures

Considering the above limitations, the study can be used to make a gross assessment of the solar thermal collector potential for process heating in industries. Further, it is to be noted that the costs of the systems reduce exponentially with capacity.

\subsection{Potential of select Indian Industries}

The industries considered in the present analysis are Textile, Pulp \& Paper, Dairy, Leather and Automobile. These industries consume $2,800 \mathrm{ktoe}$ of fuel oil for process heating in the operating temperature range of $50^{\circ} \mathrm{C}-$ $250^{\circ} \mathrm{C}$. This corresponds to $6.3 \%$ of the total consumption by all industries. The methodology presented in Section 2 can be applied to any other industry in addition to these where process heating can be achieved with solar thermal collectors.

Details of assessment in each industry and findings are presented in the sections below.

\subsubsection{Textile Industry}

In India, the Textile industry contributes $14 \%$ to the total industrial production, $4 \%$ to the GDP and $11 \%$ to the country's export earnings. This is also an energy-intensive industry and is the second largest industry in the world in terms of fiber production and employment generation (IBEF, 2014; Palanichamy and Sundar, 2005). This sector has large process variants in terms of products, namely, man-made fiber, cotton, handloom, woolen, jute, and sericulture and silk. The operating temperatures of different processes, the conventional fuels for heat generation and the potential solar collectors to retrofit the existing conventional systems in this industry are given in Table 3 (Anjali, 2012; Kalogirou, 2004; Mekhilef et al., 2011; Tanapongpipat et al., 2008).

Table 3: Suitable solar collectors in the Textile industry

\begin{tabular}{cccc}
\hline Process & $\begin{array}{c}\text { Operating } \\
\text { Temperature } \\
\left({ }^{\circ} \mathbf{C}\right)\end{array}$ & $\begin{array}{c}\text { Fuel sources } \\
\text { used }\end{array}$ & $\begin{array}{c}\text { Suitable solar } \\
\text { collector }\end{array}$ \\
\hline Sizing & $60-90$ & Electricity, & ETC \\
Scouring & $90-110$ & petroleum, & ETC \\
Bleaching & $90-95$ & coal and & ETC \\
\hline
\end{tabular}




\begin{tabular}{cccc}
\hline Mercerizing & $60-70$ & other fuels & FPC \\
Dyeing & $70-90$ & & FPC \\
Finishing & $40-100$ & & ETC \\
\hline
\end{tabular}

The Indian Textile industry has an annual fabric production capacity of about 9.6 million tons (Ministry of Textiles, 2014; The Textile Magazine, 2013). Of the total domestic production, $20 \%$ of the fabric production undergoes the processes mentioned in Table 3 via the organized sector. The thermal energy requirements of all these processes can be met through FPC and ETC solar collectors as their operating temperatures are less than $150^{\circ} \mathrm{C}$.

The potential of solar energy penetration with FPCs and ETCs in the Textile industry for various processes at national level is estimated and is given in Table 4. It can be seen that the total thermal energy demand in the Textile industry is $8.3 \times 10^{7} \mathrm{GJ} /$ year, which is similar to the observations of (Thiruchelvam et al., 2003). Of this, the solar component can supply $1.7 \times 10^{7} \mathrm{GJ} /$ year. This requires a solar collector area of $6.2 \mathrm{million} \mathrm{m}^{2}$, which requires a capital investment of US $\$ 970$ million. Details of higher solar energy penetration through thermal energy storage are presented in the sensitivity analysis in Section 4.

Table 4: Energy demands and the possibility of solar energy integration in the Textile industry

\begin{tabular}{cccc}
\hline Process & $\begin{array}{c}\text { Energy } \\
\text { demand } \\
\left(\times 10^{6}\right. \\
\text { GJ/year })\end{array}$ & $\begin{array}{c}\text { Solar } \\
\text { collector } \\
\text { area } \\
\left(\text { million } \mathrm{m}^{2}\right)\end{array}$ & $\begin{array}{c}\text { Capital cost } \\
\text { to install } \\
\text { solar } \\
(\text { US\$ million })\end{array}$ \\
\hline Sizing & 6.23 & 0.40 & 60 \\
Scouring & 12.1 & 0.87 & 128 \\
Bleaching & 6.85 & 0.45 & 67 \\
Mercerizing & 4.82 & 0.34 & 55 \\
Dyeing & 39.78 & 3.29 & 537 \\
Finishing & 13.02 & 0.82 & 122 \\
Total & $\mathbf{8 2 . 7 9}$ & $\mathbf{6 . 1 8}$ & $\mathbf{9 7 0}$ \\
\hline
\end{tabular}

The overall annual benefits are presented in Table 5. It is found that Textile industries have the potential to make fuel oil savings of about $439 \mathrm{ktoe}$. This translates to annual net monetary savings of US\$123 million and annual $\mathrm{CO}_{2}$ reductions of about $1,420 \mathrm{kt}(0.06 \%$ of total Indian emissions $)$ with the integration of solar collectors.

Table 5: Overall annual benefits of Textile industry with solar energy

\begin{tabular}{cc}
\hline Description & Value \\
\hline Fuel oil demand (ktoe) & 2,471 \\
Fuel oil saved by solar energy (ktoe) & 439 \\
Net monetary benefits (US\$ million) & 123 \\
$\mathrm{CO}_{2}$ reductions (kt) & 1,420 \\
\hline
\end{tabular}

\subsubsection{Pulp \& Paper Industry}

Pulp \& Paper is another energy-intensive industry in India with a production capacity of more than 10 million tons. India accounts for only $2 \%-3 \%$ of the global paper and paperboard production (IREDA, 2010), but the energy requirement cost through fuel accounts for nearly $25 \%$ of the overall manufacturing cost. IREDA estimated that the total annual energy consumption of the Indian paper industry is about 52 million Gcal, which is equivalent to about US\$220 million.

Processes in this industry that have scopes for integration of solar technologies are debarking, pulp making, bleaching, stock preparation and paper making. These processes are highly energy-intensive and utilize heat mainly for cleaning, boiler feed water heating and drying (Edenhofer, 2012; Gemechu et al., 2012). The operating temperatures of these processes, the fuels used for heat generation and suitable solar technologies are given in Table 6 (Mekhilef et al., 2011; The Textile Magazine, 2013). 


\begin{tabular}{cccc}
\hline Process & $\begin{array}{c}\text { Temperature } \\
\left({ }^{\circ} \mathbf{C}\right)\end{array}$ & $\begin{array}{c}\text { Existing fuel } \\
\text { source }\end{array}$ & $\begin{array}{c}\text { Suitable } \\
\text { solar }\end{array}$ \\
\hline Cooking, drying & $60-80$ & Fuel oil, pet & FPC \\
Boiler feed water & $60-90$ & coke, rice husk & FPC \\
Bleaching & $130-150$ & and coal & ETC \\
\hline
\end{tabular}

The solar energy potential estimation is done based on the gross production and thermal energy requirements (ComSolar, 2011; IPMA, 2014). Details are given in Table 7. It can be seen that the solar component can supply 2.5 PJ of energy. However, estimates made by (Sharma et al., 2016) indicate that the total process heating potential of the Pulp \& Paper industry in India is $25.2 \mathrm{PJ} /$ annum. This estimation has been arrived at based on the fact that the industry uses the parabolic trough technology, which supplies energy at high temperatures. However, the present paper production process considers FPCs and ETCs for preheating at $70^{\circ} \mathrm{C}$. It can also be seen that the total solar collector area required is 0.9 million $\mathrm{m}^{2}$ and the capital cost is US\$149 million.

Table 7: Energy demands and the possibility of solar energy integration in the Pulp \& Paper industry

\begin{tabular}{ccc}
\hline Description & Quantity & Units \\
\hline Total production of paper and paperboard & 10.11 & Million tons/year \\
Hot water requirement for preheating @ $70^{\circ} \mathrm{C}$ & 6.5 & Tons/ton of paper \\
Energy required & 12.38 & PJ/year \\
Energy from solar collectors & 2.48 & $\mathrm{PJ} /$ year \\
Solar collector area required & 0.91 & Million m \\
Capital cost for solar collectors & 149 & US\$ million \\
\hline
\end{tabular}

Further, it can be seen from Table 8 that the total fuel oil required for all the processes is about 329 ktoe. However, the amount of fuel that can be saved through the solar component is $66 \mathrm{ktoe}$, with annual $\mathrm{CO}_{2}$ reductions of about $213 \mathrm{kt}$. The net monetary savings due to replacement with the solar component is US $\$ 18.3$ million.

Table 8: Overall annual benefits in the Pulp \& Paper industry with solar energy

\begin{tabular}{ccc}
\hline Description & Quantity & Units \\
\hline Fuel oil demand & 329 & ktoe \\
Fuel oil saved by solar energy & 66 & ktoe \\
Net monetary benefits & 18.3 & US\$ million \\
$\mathrm{CO}_{2}$ reductions & 210 & $\mathrm{kt}$ \\
\hline
\end{tabular}

\subsubsection{Dairy Industry}

The Dairy industry in India accounts for $13 \%$ of the global milk production. The annual growth rate in milk production was about 4\% in 2002-12. In FY 2010-11, 122 million tons of milk were produced and it is expected that milk production will exceed 140 million tons in 2014 (Indiastat, 2014). In India, only 13\% of the total milk production is processed by the organized sector. The shares of hot water and thermal energy consumption by various processes and their operating temperatures in the Dairy industry are given in Table 9 (ComSolar, 2011; Mekhilef et al., 2011; Müller et al., 2014).

Table 9: Suitable solar collectors in Dairy industry

\begin{tabular}{lcccc}
\hline \multicolumn{1}{c}{ Process } & $\begin{array}{c}\text { Water } \\
\text { consumption } \\
(\boldsymbol{\%})\end{array}$ & $\begin{array}{c}\text { Energy } \\
\text { consumption } \\
(\boldsymbol{\%})\end{array}$ & $\begin{array}{c}\text { Temperature } \\
\left({ }^{\circ} \mathbf{C}\right)\end{array}$ & $\begin{array}{c}\text { Suitable } \\
\text { solar } \\
\text { collector }\end{array}$ \\
\hline Cleaning & 18 & 5 & $40-60$ & FPC \\
Pasteurization, Sterilization & 18 & 36 & $70-120$ & ETC \\
and Evaporation (PSE) & 12 & 3 & $35-45$ & FPC \\
Pre-heating & 40 & 36 & - & \\
Incorporated into products & 12 & 20 & - & \\
Other purposes & & &
\end{tabular}


As per national norms, $0.034 \mathrm{kWh}$ of electricity, $5 \mathrm{ml}$ of fuel oil and 2 liters of water are required to process 1 liter of milk (ComSolar, 2011; Xu and Flapper, 2009). This is equivalent to about $0.33 \mathrm{MJ}$ of energy. The thermal energy requirements for the processes mentioned above and the potential for solar energy penetration with FPCs and ETCs in the Dairy industry are given in Table 10. It can be seen that the solar component can supply $0.49 \mathrm{PJ}$ of thermal energy. The total solar collector area required to supply this energy is about 0.16 million $\mathrm{m}^{2}$ with an associated capital cost of US $\$ 25$ million.

Table 10: Energy requirements and potential in the Dairy Industry

\begin{tabular}{lcccc}
\hline \multicolumn{1}{c}{ Process } & $\begin{array}{c}\text { Thermal Energy } \\
(\mathbf{P J})\end{array}$ & $\begin{array}{c}\text { Thermal } \\
\text { energy from } \\
\text { solar } \mathbf{( P J )}\end{array}$ & $\begin{array}{c}\text { Collector area } \\
\left.\text { (Million } \mathbf{~ m}^{\mathbf{2}}\right)\end{array}$ & $\begin{array}{c}\text { Capital cost } \\
\text { (US\$ } \\
\text { million) }\end{array}$ \\
\hline Cleaning & 0.58 & 0.12 & 0.035 & 2.8 \\
PSE & 1.62 & 0.32 & 0.12 & 17.2 \\
Pre-heating processes & 0.23 & 0.05 & 0.013 & 2.1 \\
\hline
\end{tabular}

Details of fuel oil and monetary savings with integration of solar collectors in this industry are given in Table 11. The Dairy industry requires about $64.6 \mathrm{ktoe}$ of fuel oil for process heating. Installation of solar components can bring in fuel oil savings of 12.9 ktoe and annual $\mathrm{CO}_{2}$ reductions of about $41 \mathrm{kt}$.

Table 11: Overall annual benefits in the Dairy industry with solar energy

\begin{tabular}{lc}
\hline \multicolumn{1}{c}{ Parameter } & Value \\
\hline Fuel oil demand (ktoe) & 64.6 \\
Fuel oil saved by solar (ktoe) & 12.9 \\
$\mathrm{CO}_{2}$ reductions (kt) & 41 \\
Net monetary benefits (US\$ million) & 3.7 \\
\hline
\end{tabular}

\subsubsection{Leather Industry}

The Indian Leather industry occupies a prominent position on account of considerable export earnings, employment generation and various consumer products. Of the total production, the organized sector accounts for $56.4 \%$ and the un-organized sector accounts for $43.6 \%$. Table 12 shows the operating temperatures and fuels used for heat generation in the tanning sector of the Leather industry (ComSolar, 2011).

Table 12: Suitable solar collectors in the Leather industry

\begin{tabular}{cccc}
\hline Process & $\begin{array}{c}\text { Temperature } \\
\left({ }^{\circ} \mathbf{C}\right)\end{array}$ & Fuel being used & $\begin{array}{c}\text { Suitable } \\
\text { solar }\end{array}$ \\
\hline Pre-tanning & $40-60$ & Fuel oil, rice & FPC \\
Tanning & $60-80$ & husk, firewood, & FPC \\
Post-tanning & $70-100$ & coal & ETC \\
\hline
\end{tabular}

Tanning operations (soaking, liming, pickling, splitting, dyeing, etc.) consume most of the thermal energy in terms of heating water to a temperature of $40^{\circ} \mathrm{C}-80^{\circ} \mathrm{C}$ and air to a temperature of $70^{\circ} \mathrm{C}-100^{\circ} \mathrm{C}$. This accounts for $40 \%$ of the total thermal energy consumption in the Leather industry (Buddhadeb, 2010). The total capacity of Indian tanning units is around 2 billion sq. $\mathrm{ft}$. of hide/skin (annual production of about 0.7 million tons), with about 1,600 kcal of thermal energy required to process $1 \mathrm{~kg}$ of hide/skin. Leather industry consumes about 21 billion liters of water annually. The solar energy potential in the Leather industry is estimated and presented in Table 13 (ComSolar, 2011; Council for Leather Exports, 2014).

It can be seen that the hot water accounts for 8.4 billion liters, requiring thermal energy of 4.4 PJ per annum ( $31 \%$ for hot water and $63 \%$ for hot air). The industry has potential of about 0.27 million $\mathrm{m}^{2}$ for ETC solar collectors to supply thermal energy, which requires an investment of US\$40 million. 
Table 13: Process requirements and solar energy potential in the Leather industry

\begin{tabular}{cc}
\hline Parameter & Value \\
\hline Hot water requirement (billion liters/annum) & 8.4 \\
Energy requirement for hot water (PJ/annum) & 1.47 \\
Energy requirement for drying (PJ/annum) & 2.93 \\
Energy for hot water from solar collectors (PJ/annum) & 0.29 \\
Energy for drying from solar collectors (PJ/annum) & 0.59 \\
Solar collector area required (million m $^{2}$ ) & 0.27 \\
Capital cost for solar collectors (US\$ million) & 40 \\
\hline
\end{tabular}

Further, it can be seen from Table 14 that 23 ktoe of oil savings translate to net monetary savings of US\$6.7 million and $75 \mathrm{kt}$ of $\mathrm{CO}_{2}$ reduction.

Table 14: Overall annual benefits in the Leather industry with solar energy

\begin{tabular}{cc}
\hline Parameter & Value \\
\hline Fuel oil demand (ktoe) & 116 \\
Fuel oil savings due to solar energy (ktoe) & 23 \\
Annual $\mathrm{CO}_{2}$ reductions (kt) & 75 \\
Net annual monetary savings (US\$ million) & 6.7 \\
\hline
\end{tabular}

\subsubsection{Automobile Industry}

The Indian Automobile industry is one of the largest markets in the world. In FY 2012-13, the industry manufactured about 16 million vehicles (IBEF, 2014), and growth is expected to be more than $13 \%$ per annum in 2012-2021 (Kulkarni et al., 2014). The consumption of fossil fuels for the heat requirements in this industry is significant and is of the order of 1,000 ktoe/annum.

Most of the processes in the Automobile industry are mechanical and are driven by electricity. However, a few processes require considerable amount of thermal energy for drying and cleaning. Generally, drying is done by blowing hot air and cleaning by using hot water. The operating temperatures of these processes, the fuels used for heat generation and suitable solar technologies are given in Table 15. The energy consumption of the processes is analyzed considering an equivalent passenger vehicle. Therefore, for every vehicle, a weight factor is assigned with respect to the energy consumption of an equivalent passenger vehicle. The equivalent weight factors for two- and three-wheelers, small commercial vehicles, construction vehicles and heavy commercial vehicles are $0.5,2,3.7$, and 4 , respectively. The thermal energy requirement for air heating at $200^{\circ} \mathrm{C}$ is about $1,000 \mathrm{kcal} / \mathrm{Eq}$. vehicle and is about 1,000 liter/car for heating water at $95^{\circ} \mathrm{C}(\mathrm{ACMA}, 2009$; ComSolar, 2011).

Table 15: Suitable solar collectors in the Automobile industry

\begin{tabular}{cccc}
\hline Process & $\begin{array}{c}\text { Temperature } \\
\left({ }^{\circ} \mathbf{C}\right)\end{array}$ & Fuel being used & $\begin{array}{c}\text { Suitable } \\
\text { solar }\end{array}$ \\
\hline Hot water & $85-95$ & Fuel oil, & ETC \\
Drying (hot air) & $\sim 200$ & Electricity & Dish \\
\hline
\end{tabular}

The thermal energy requirements and solar energy potential in the Automobile industry are estimated and presented in Table 16. It can be noted that a dish collector is used for drying at $200^{\circ} \mathrm{C}$ and an ETC is used for generating hot water at $95^{\circ} \mathrm{C}$. This industry has a potential of 0.29 million $\mathrm{m}^{2}$ for solar collectors. 
Table 16: Energy demands and the possibility of solar energy integration in the Automobile industry

\begin{tabular}{ccc}
\hline Parameter & \multicolumn{2}{c}{ Value } \\
\cline { 2 - 3 } & Dish (drying) & ETC (water heating) \\
\hline Total thermal energy per annum (PJ/annum) & 0.07 & 4.34 \\
Thermal energy from solar (PJ/annum) & 0.013 & 0.87 \\
Collector area (million m $^{2}$ ) & 0.005 & 0.29 \\
Capital cost (US\$ million) & 1.57 & 43.4 \\
\hline
\end{tabular}

Table 17 provides the overall benefits due to penetration of solar energy in the Automobile industry. It can be seen that annual net monetary savings of US\$18.15 million and total annual $\mathrm{CO}_{2}$ reductions of about $76 \mathrm{kt}$ can be achieved by using solar collectors.

Table 17: Overall annual benefits in the Automobile industry with solar energy

\begin{tabular}{ccc}
\hline Parameter & \multicolumn{2}{c}{ Value } \\
\cline { 2 - 3 } & Dish & ETC \\
\hline Fuel oil demand (ktoe) & 1.8 & 115 \\
Fuel oil savings (ktoe) & 0.36 & 23 \\
Net monetary savings (US\$ million) & 0.1 & 6.5 \\
$\mathrm{CO}_{2}$ reductions (kt) & 1.2 & 75 \\
\hline
\end{tabular}

\section{Summary of Solar Energy Potential in the selected Industries}

The overall potential of solar energy and the benefits for process heating in the Indian Textile, Pulp \& Paper, Dairy, Leather and Automobile industries are given in Table 18. These industries have potential for fuel oil savings of anywhere between 565 ktoe and 2,827 ktoe using solar energy integration for process heating. With $20 \%$ solar energy integration, these industries require about 7.8 million $\mathrm{m}^{2}$ of solar collector area with an investment of US\$1200 million. This will have annual net monetary benefits of US\$158 million, with $1.8 \mathrm{Mt}$ of $\mathrm{CO}_{2}$ load reduction to the environment.

Table 18: Overall potential of solar energy in the selected industries

\begin{tabular}{ccccccc}
\hline $\begin{array}{c}\text { Industry } \\
\text { type }\end{array}$ & $\begin{array}{c}\text { Fuel oil } \\
\text { demand } \\
\text { (ktoe) }\end{array}$ & $\begin{array}{c}\text { Fuel oil } \\
\text { savings } \\
\text { by } \\
\text { solar } \\
\text { energy } \\
\text { (ktoe) }\end{array}$ & $\begin{array}{c}\text { Solar } \\
\text { collector } \\
\text { area } \\
\left(\begin{array}{c}\text { million } \\
\mathbf{m}^{\mathbf{2}} \text { ) }\end{array}\right.\end{array}$ & $\begin{array}{c}\text { Capital cost } \\
\text { to install } \\
\text { solar } \\
\text { collectors } \\
\text { (US\$ } \\
\text { million) }\end{array}$ & $\begin{array}{c}\text { Net } \\
\text { monetary } \\
\text { savings } \\
\text { (US\$ } \\
\text { million) }\end{array}$ & $\begin{array}{c}\mathbf{C O}_{\mathbf{2}} \\
\text { emission } \\
\text { reduction } \\
\text { (Mt CO } \\
\text { /year) }\end{array}$ \\
\hline Textile & 2,197 & 439 & 6.2 & 970 & 123 & 1.42 \\
Pulp \& Paper & 329 & 66 & 0.9 & 149 & 18.3 & 0.22 \\
Dairy & 65 & 13 & 0.16 & 25 & 3.7 & 0.05 \\
Leather & 117 & 23 & 0.27 & 40 & 6.7 & 0.08 \\
Automobile & 117 & 23 & 0.30 & 45 & 6.6 & 0.08 \\
Total & $\mathbf{2 , 8 2 7}$ & $\mathbf{5 6 5}$ & $\mathbf{7 . 8}$ & $\mathbf{1 , 2 2 9}$ & $\mathbf{1 5 8}$ & $\mathbf{1 . 8}$ \\
\hline
\end{tabular}

\section{Sensitivity Analysis}

A parametric study has been performed in this section with respect to key sensitive parameters. This analysis helps in making decisions on the implementation of these systems. The study identified capital cost, fuel oil savings, IRR, DPP, and carbon savings to be the major output parameters. The analysis that follows investigates the effect of key input parameters on these outputs.

\subsection{Effect of Solar Energy Penetration}

Fig. 4 shows the variation of capital cost and solar collector area for various penetration scenarios. The thermal energy storage cost is also accounted for the capital cost for higher solar energy penetration. It may be noted that the capital cost for 20\%-100\% solar penetration varies from US\$1200 to US\$6100 million with a solar collector area of 7.8-40 million $\mathrm{m}^{2}$. The corresponding supply of thermal energy is $21-106 \mathrm{PJ}$. The actual 
capital costs of solar collectors depend on the scale of the particular installation, which further depends on the scale of the actual industrial unit/plant. This has not been considered in this study and could be further examined depending on the scale of the system. The capital cost may decrease exponentially for systems of higher size. However, the present study is useful to assess the scale of costs and savings through installation of solar collectors.

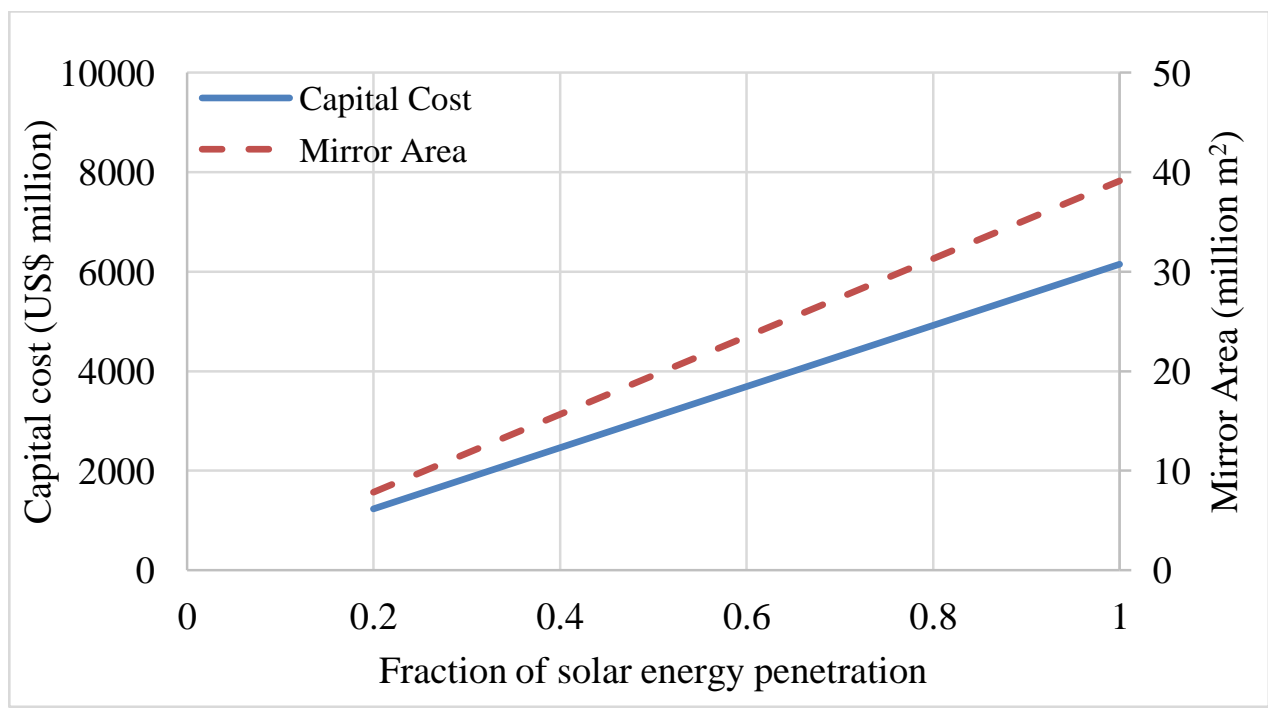

Fig. 4: Variation of Capital Cost and Collector Area with Solar Energy Penetration

Fig. 5 shows the variation of fuel oil and carbon emission savings with solar energy penetration. It is important to note that fuel oil and carbon emission savings are increase proportionately with solar energy penetration. With 20\%-100\% solar energy penetration, these savings amount to 565-2827 ktoe and 1.68-9.0 $\mathrm{Mt} \mathrm{CO}_{2}$, respectively. $100 \%$ solar penetration (equivalent to $2,827 \mathrm{ktoe}$ ) in these industries could reduce the total oil consumption in all industries by $6.5 \%$. As indicated in Section 2.6, the savings of fuel oil will be proportional to the energy supplied by the solar collectors. Therefore, the fuel oil savings and carbon savings will be in linear proportion with the energy savings through solar energy.

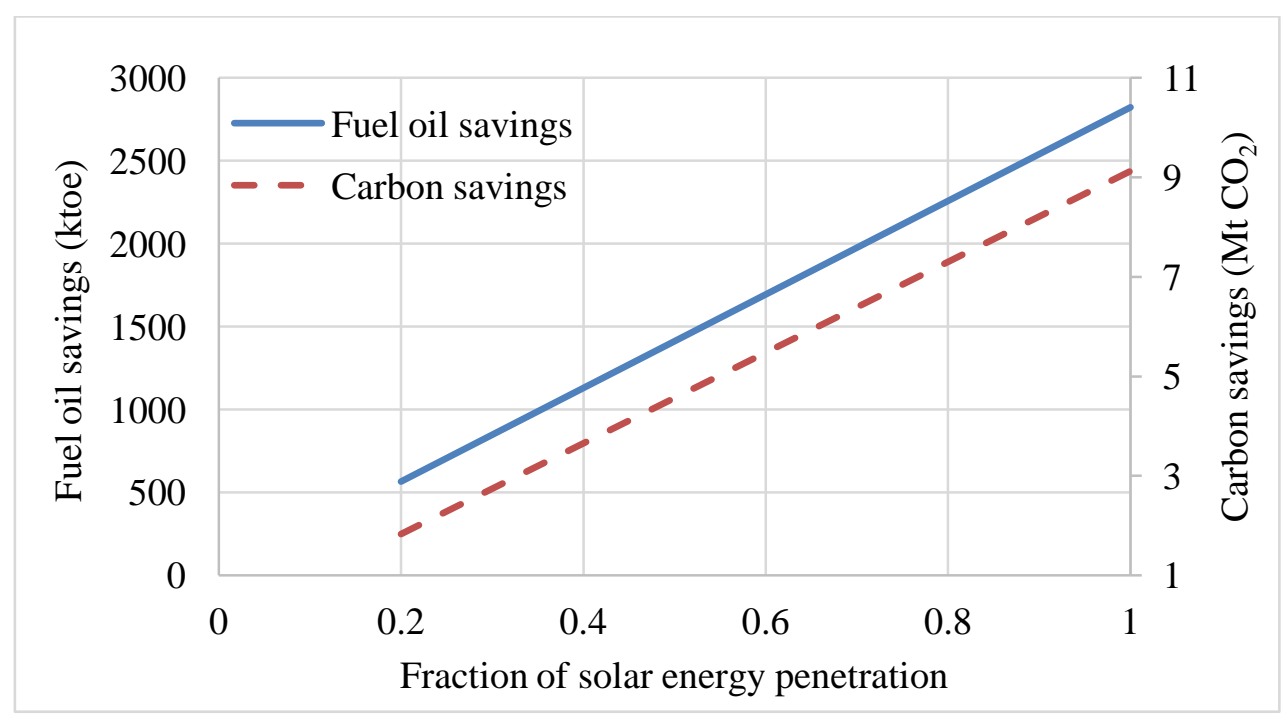

Fig. 5: Variation of Fuel oil and $\mathrm{CO}_{2}$ emission savings with Solar Energy Penetration

\subsection{Effect of Fuel Oil Price}

The influence of fuel oil price on the DPP and the IRR is investigated in this section. Fig. 6 shows the variation of fuel oil price from 2006 to 2016 (Indexmundi, 2016). 


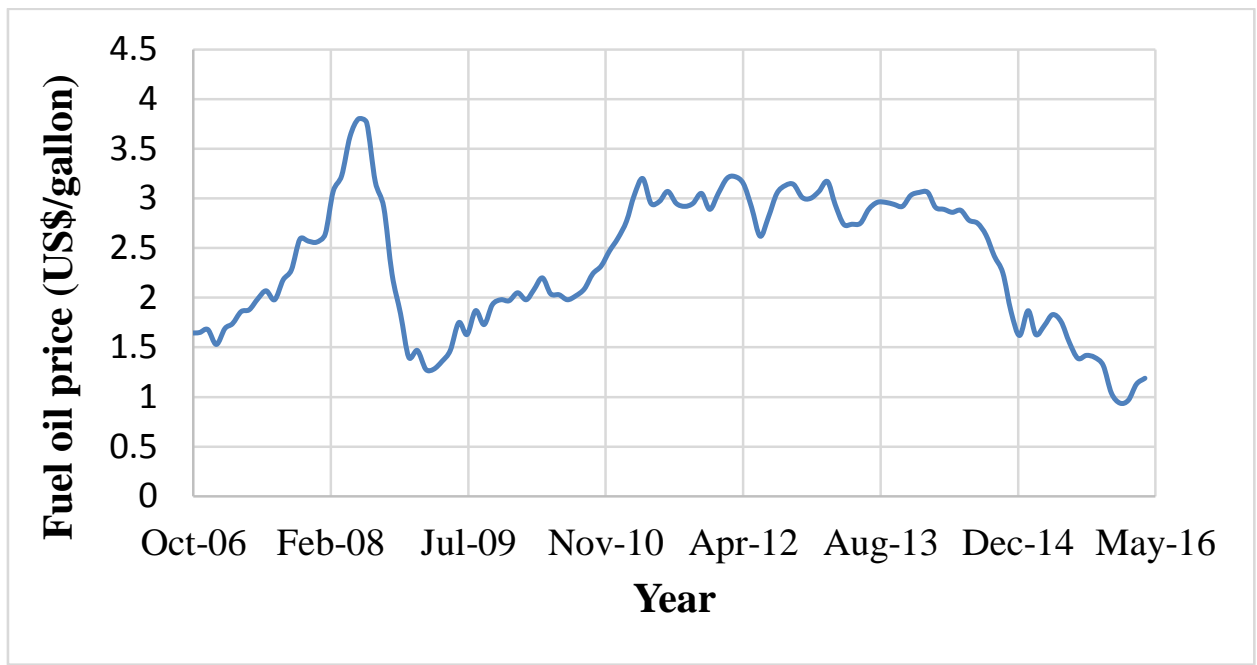

Fig. 6: Trend of Fuel Oil Price for India in the Past Decade

Fig. 6 shows that the price of fuel oil varied continuously over the past decade. It is important to note that the price of fuel oil was increasing during the period 2009-12, over which many initiatives were launched by the Government of India to increase the penetration of solar energy. Further, subsidies on both the capital cost for captive installation and the purchase cost of energy from solar were also offered to promote solar energy for various applications. Since 2013, the price of fuel oil started falling. Fig. 7 and Fig. 8 show the effects of this fall on the DPP and IRR of low-temperature solar collectors (FPC and ETC) and high-temperature collectors (Dish), respectively. It is to be noted that subsidies on solar thermal collectors were discontinued in 2014. The DPP and IRR are arrived at by considering $10 \%$ discount rate for LTCs and $5 \%$ for HTCs, $2 \%$ of capital cost for $\mathrm{O} \& \mathrm{M}$, and a $2 \%$ escalation in O\&M for every year.

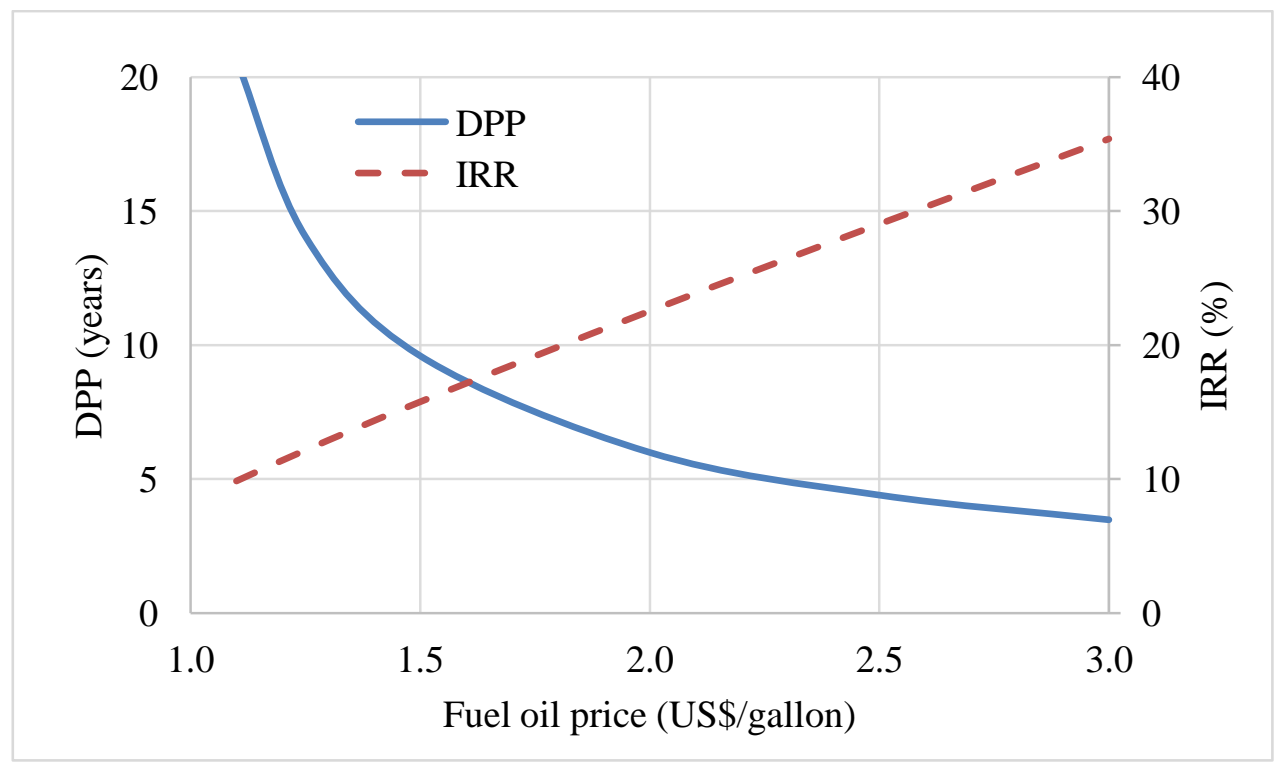

Fig. 7: Variation of DPP and IRR with Fuel oil price for LTCs

As can be seen from Fig. 7, both DPP and IRR of solar thermal collectors are sensitive to changes in fuel oil price. With increase in fuel oil price, DPP decreases exponentially whereas IRR increases proportionately. At a fuel price of US\$1.19 per gallon (present oil price), the DPP of solar collectors is over 20 years (exceeds the life of LTCs) and the IRR is $9.8 \%$. In this condition, solar collectors are strictly not a viable option. However, DPP decreases to 4.5 years and IRR increases to $29 \%$ when the fuel oil price exceeds US\$2.5 per gallon (similar to the rates in the period between 2010 and 2014). 
A similar exercise for a Dish collector is presented in Fig. 8. The DPP and IRR figures indicate that Dish collectors for process heating are not viable with the preset capital costs of solar collectors and fuel oil prices. However, when the fuel price is above US\$2.5 per gallon, DPP is around 14 years and IRR is $13 \%$, which is slightly viable. Further, it is to be noted that dish collectors can offer higher temperatures $\left(150^{\circ} \mathrm{C}-400^{\circ} \mathrm{C}\right)$ and a longer lifetime (25-30 years).

These parameters can be optimized, but that depends on system costs, scale of the systems, solar irradiance and fuel oil prices. It is obvious that any investor will expect high returns and lower payback periods. At the present state, suitable solutions are largely dependent on fuel oil price. A possible solution could be when fuel oil price is $>1.8 \$$ /gallon, at which the DPP is $<7$ years and IRR is $>20 \%$ for the LTCs. And, for the dish collectors, the fuel oil price has to be $>2.5 \$$ /gallon, at which the DPP is $<15$ years and IRR is $>13 \%$.

Overall, the viability of solar collectors will highly depend on the price of fuel oil unless the capital cost of solar collectors falls or subsidies are offered.

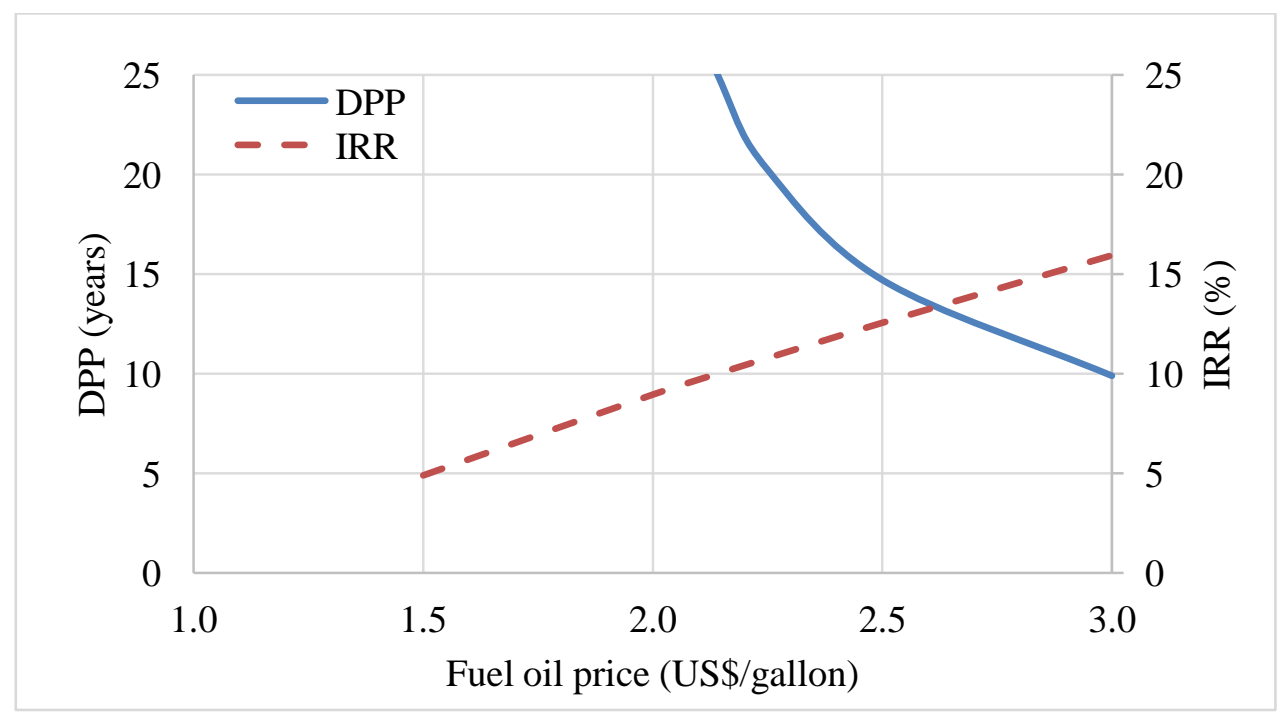

Fig. 8: Variation of DPP and IRR with Fuel Oil Price for Dish Collectors

\section{Policy Recommendations}

India has installed about $40,000 \mathrm{~m}^{2}$ of solar collector area for process heating so far. However, the penetration of solar energy for process heating has to be increased substantially if the government is to meet its set NDCs. In this regard, the study proposes the following policy recommendations to meet the NDC targets:

- A mandate to for energy audits assess the true energy demands and space availability of all industries for solar integration

- Mandate for a focus on process heating (and electricity generation) through solar route in all industries, given that conversion efficiency is far greater in process heating applications

- Regulations on fossil fuel use and emission rates in industries

- Mandate of renewable energy mix for all existing and upcoming industries

- Fiscal benefits for industries which use solar energy for process heating

- Dissemination of information and advantages of solar systems for process heating

- Research \& Development for robust solar systems with reduced cost

\section{Conclusion}

In this study, a generalized methodology is developed to estimate the potential of solar thermal collectors for industrial process heating. This methodology has been applied to verify the potential of select Indian industries that have scope for integration of solar collectors. In the selected industries, namely, Textile, Pulp \& Paper, Dairy, Leather and Automobiles, the majority of the processes need thermal energy with an operating temperature range of $50^{\circ} \mathrm{C}-250^{\circ} \mathrm{C}$. FPCs, ETCs and Dish collectors are considered for operating temperatures up to $80^{\circ} \mathrm{C}, 80^{\circ} \mathrm{C}-150^{\circ} \mathrm{C}$ and $>150^{\circ} \mathrm{C}$, respectively. 
The selected industries have a total annual thermal energy demand of $106 \mathrm{PJ}$, which is equivalent to 2,800 ktoe. The sensitivity of the capital cost, DPP and IRR was analyzed with respect to solar energy penetration and fuel oil price. The study found that $20 \%$ solar energy penetration to meet the energy demand in the selected industries would translate to fuel oil savings of 565 ktoe and carbon savings of $1.8 \mathrm{Mt} \mathrm{CO}_{2}$. However, this requires a capital investment of US $\$ 1,200$ million to set up 7.8 million $\mathrm{m}^{2}$ of solar collector area. The corresponding annual net monetary savings after accounting for O\&M is US\$158 million. For $100 \%$ solar energy penetration with thermal energy storage, the fuel oil and carbon savings are 2,800 ktoe and $9.1 \mathrm{Mt} \mathrm{CO}_{2}$, respectively. This requires a capital investment of US $\$ 6,000$ million to set up 39 million $\mathrm{m}^{2}$ of solar collector area. The net monetary savings per annum with $100 \%$ solar energy penetration is US\$800 million. The selected industries have the potential to reduce India's carbon emissions by $0.1 \%-0.4 \%$. Further, they have the potential to reduce the fuel oil consumption by $6.3 \%$ (equivalent to $1.5 \%$ oil imports) of the total industries in India.

Though the above figures look promising, further investigation has been performed on DPP and IRR through sensitivity analysis. The percentage of solar energy penetration has little impact on DPP and IRR. In contrast, fuel oil price and discount rates (the former has a higher impact) greatly affect DPP and IRR.

The DPPs of the system for fuel oil prices of US\$1 per gallon and US\$3 per gallon are 20 years and 3.5 years, respectively. The corresponding IRRs for the same fuel prices are $9.8 \%$ and $35 \%$, respectively. The option of integrating solar collectors is not viable considering the present fuel oil prices. However, it is viable if the fuel price exceeds US\$2/gallon (IRR-23\% and DPP-6 years for LTC; IRR-13\% and DPP-15 years for Dish). Therefore, unless the capital cost of solar collectors decrease or subsidies are offered, their viability will highly depend on the price of fuel oil.

The actual capital costs of solar collectors and the monetary savings depend on the scale of the particular installation, which further depends on the scale of the actual industrial unit/plant. This has not been considered in this study and could be further examined depending on the scale of the system. However, the present study is useful to assess the scale of costs and savings through installation of solar collectors.

The study highlights the fact that the conversion efficiency for solar energy is much higher for process heating applications as compared to electricity generation and provides compelling engineering economic analyses for specific industrial sectors. This study suggests several policy recommendations that could be considered to encourage industries to take up solar based process heating in an intensive manner.

\section{Acknowledgements}

This work is supported by the US-India Partnership to Advance Clean Energy-Research (PACE-R) for the Solar Energy Research Institute for India and the United States (SERIIUS), funded jointly by the U.S. Department of Energy and the Government of India, through the Department of Science and Technology under Subcontract IUSSTF/JCERDC-SERIIUS/2012. The authors are grateful to Dr. Anshu Bharadwaj and Dr. Jai Asundi for encouragement, support and guidance. The authors are also thankful to Dr. S.S. Krishnan, Dr. Mridula Bharadwaj, Thirumalai N C and Sahil Ali for critical reviews and Abhijit Chakraborty for editing inputs on the manuscript. 


\section{References}

ACMA, 2009. Auto Component Industry in India: Growing Capabilities \& Strengths. The Automotive Component Manufacturers Association of India.

Adams, S., Klobodu, E.K.M., Opoku, E.E.O., 2016. Energy consumption, political regime and economic growth in sub-Saharan Africa. Energy Policy 96, 36-44. doi:10.1016/j.enpol.2016.05.029

Anjali, B., 2012. Solar energy applications in the textile sector: Commercialization of solar energy in urban and industrial areas.

Ashok, K.S., 2015. Energy intensity and carbon market for climate justice. Int. J. Eng. Appl. Sci. 2.

Buddhadeb, C., 2010. Eco-compatibility: Green chemistry.

Carbon Trust, 2016. Conversion factors. The Carbon Trust, London.

Carnevale, E.A., Ferrari, L., Paganelli, S., 2011. Investigation on the feasibility of integration of high temperature solar energy in a textile factory. Renew. Energy 36, 3517-3529. doi:10.1016/j.renene.2011.06.001

CEA, 2016. Installed capacity. Central Electricity Authority, New Delhi.

CLE, 2014. Industry at Glance. Council for Leather Industry sponsored by Ministry of Commerce \& Industry, Govt. of India.

ComSolar, 2011. Identification of Industrial Sectors Promising for Commercialisation of Solar Energy. New Delhi.

Dawn, S., Tiwari, P.K., Goswami, A.K., Mishra, M.K., 2016. Recent developments of solar energy in India: Perspectives, strategies and future goals. Renew. Sustain. Energy Rev. 62, 215-235. doi:10.1016/j.rser.2016.04.040

Edenhofer, O., 2012. Special report on renewable energy sources and climate change mitigation: summary for policymakers and technical summary. Intergovernmental Panel on Climate change, Geneva.

EIA, 2013. India is the fourth largest energy consumer in the world. U.S. Energy Information Administration.

ESTTP, 2008. Solar Heating and Cooling for a Sustainable Energy Future in Europe. European Solar Thermal Technology Platform, Belgium.

ETSAP, IRENA, 2015. Solar Heat for Industrial Processes - Technology Brief. The International Renewable Energy Agency (IRENA) and The Energy Technology Systems Analysis Programme (ETSAP) by the International Energy Agency (IEA).

Fernández-García, A., Rojas, E., Pérez, M., Silva, R., Hernández-Escobedo, Q., Manzano-Agugliaro, F., 2015. A parabolic-trough collector for cleaner industrial process heat. J. Clean. Prod. 89, 272-285. doi:10.1016/j.jclepro.2014.11.018

Fuller, R.J., 2011. Solar industrial process heating in Australia - Past and current status. Renew. Energy 36, 216-221. doi:10.1016/j.renene.2010.06.023

Gemechu, E.D., Butnar, I., Llop, M., Castells, F., 2012. Environmental tax on products and services based on their carbon footprint: A case study of the pulp and paper sector. Energy Policy 50, 336-344. doi:10.1016/j.enpol.2012.07.028

IBEF, 2014. Automobiles - Sectorial Report. India Brand Equity Foundation, New Delhi.

Indexmundi, 2016. Heating oil daily Price. Heat. Oil Dly. Price.

Indiastat, 2014. Port-wise Bunker Fuel Prices for Vessels Plying on Coastal Run-Furnace Oil in India.

IPMA, 2014. Paper Industry Overview by Indian Paper Manufacturers Association.

IREDA, 2010. Investors Manual for Energy Efficiency. Confederation of Indian Industry, Indian Renewable Energy Development Agency Ltd.

Kalogirou, S., 2003. The potential of solar industrial process heat applications. Appl. Energy 76, 337-361. doi:10.1016/S0306-2619(02)00176-9

Kalogirou, S.A., 1999. Performance enhancement of an integrated collector storage hot water system. Renew. Energy 16, 652-655. doi:10.1016/S0960-1481(98)00245-6

Kalogirou, S.A., 2004. Solar thermal collectors and applications. Prog. Energy Combust. Sci. 30, $231-295$. doi:10.1016/j.pecs.2004.02.001

Kanagawa, M., Nakata, T., 2007. Analysis of the energy access improvement and its socio-economic impacts in rural areas of developing countries. Ecol. Econ. 62, 319-329. doi:10.1016/j.ecolecon.2006.06.005

Karbuz, S., 2004. Conversion factors and oil statistics. Energy Policy 32, 41-45. doi:10.1016/S03014215(02)00249-5

Kedare, S.B., Ashok D. Paranjape, Rajkumar Porwal, 2012. ARUN Solar Concentrator for Industrial Process Heat Applications. Indian Institute of Technology Bombay (IITB), Clique Developments Pvt. 1td, Mahanand Dairy, Mumbai.

Khare, V., Nema, S., Baredar, P., 2013. Status of solar wind renewable energy in India. Renew. Sustain. Energy Rev. 27, 1-10. doi:10.1016/j.rser.2013.06.018 
Koroneos, C.J., Nanaki, E.A., 2012. Life cycle environmental impact assessment of a solar water heater. J. Clean. Prod. 37, 154-161. doi:10.1016/j.jclepro.2012.07.001

Kulkarni, G.N., Kedare, S.B., Bandyopadhyay, S., 2008. Design of solar thermal systems utilizing pressurized hot water storage for industrial applications. Sol. Energy 82, 686-699. doi:10.1016/j.solener.2008.02.011

Kulkarni, S., Rao, P., Patil, Y., 2014. Are the Non-renewable Resource Utilization and Waste Management Practices Employed in Indian Automobile Sector Sustainable? Procedia - Soc. Behav. Sci. 133, 364 371. doi:10.1016/j.sbspro.2014.04.202

Liu, Z., 2016. National carbon emissions from the industry process: Production of glass, soda ash, ammonia, calcium carbide and alumina. Appl. Energy 166, 239-244. doi:10.1016/j.apenergy.2015.11.005

MA Ramaswamy, VS Chandrasekaran, R Krishnan, NC Thirumalai, NS Suresh, Badri S Rao, Smita Kumari Dolly, V Chaitanya Kanth, V Arun Kumar, 2012. Engineering Economic Policy Assessment of Concentrating Solar Thermal Power Technologies for India. Center for Study of Science Technology and Policy, Bangalore.

Mauthner, F., Werner, W., 2014. Solar heat worldwide - Markets and Contribution to the Energy Supply. International Energy Agency (IEA), Gleisdorf, Austria.

Mekhilef, S., Saidur, R., Safari, A., 2011. A review on solar energy use in industries. Renew. Sustain. Energy Rev. 15, 1777-1790. doi:10.1016/j.rser.2010.12.018

Ministry of Textiles, 2014. Annual Report 2012-13.

MNRE, 2010. The Jawaharlal Nehru National Solar Mission.

MPNG, 2015. Basic Statistics on Indian Petroleum \& Natural Gas. Ministry of Petroleum \& Natural Gas, Government of India. New Delhi, New Delhi.

Müller, H., Brandmayr, S., Zörner, W., 2014. Development of an Evaluation Methodology for the Potential of Solar-thermal Energy Use in the Food Industry. Energy Procedia 48, 1194-1201. doi:10.1016/j.egypro.2014.02.135

NREL, 2015. India Solar Resource Maps \& Data.

Palanichamy, C., Sundar, B.N., 2005. Second stage energy conservation experience with a textile industry. Energy Policy 33, 603-609. doi:10.1016/j.enpol.2003.09.004

Purohit, I., Purohit, P., Shekhar, S., 2013. Evaluating the potential of concentrating solar power generation in Northwestern India. Energy Policy 62, 157-175. doi:10.1016/j.enpol.2013.06.069

Rastogi, C., 2014. Changing Geo-politics of Oil and the Impact on India. Procedia - Soc. Behav. Sci. 133, 93105. doi:10.1016/j.sbspro.2014.04.173

Schnitzer, H., Brunner, C., Gwehenberger, G., 2007. Minimizing greenhouse gas emissions through the application of solar thermal energy in industrial processes. J. Clean. Prod. 15, 1271-1286. doi:10.1016/j.jclepro.2006.07.023

SERIIUS, 2016. Solar Energy Research Institute for India and the United States.

Sharma, A.K., Sharma, C., Mullick, S.C., Kandpal, T.C., 2016. Carbon mitigation potential of solar industrial process heating: paper industry in India. J. Clean. Prod. 112, 1683-1691. doi:10.1016/j.jclepro.2015.04.093

Silva, R., Berenguel, M., Pérez, M., Fernández-Garcia, A., 2014. Thermo-economic design optimization of parabolic trough solar plants for industrial process heat applications with memetic algorithms. Appl. Energy 113, 603-614. doi:10.1016/j.apenergy.2013.08.017

Sudheer, P.S., 2015. Can India halve oil import dependence by 2030? Bus. Stand.

Tanapongpipat, A., Khamman, C., Pruksathorm, K., Hunsom, M., 2008. Process modification in the scouring process of textile industry. J. Clean. Prod. 16, 152-158. doi:10.1016/j.jclepro.2006.06.016

Tchanche, B.F., 2015. Solar Industrial Process Heat.

The Textile Magazine, 2013. World fibre production grows to 82 million tonnes in 2012. The Textile Magazine.

Thiruchelvam, M., Kumar, S., Visvanathan, C., 2003. Policy options to promote energy efficient and environmentally sound technologies in small- and medium-scale industries. Energy Policy 31, 977 987. doi:10.1016/S0301-4215(02)00140-4

Trading Economics, 2016. India imports: 1957-2016.

UNDP, 2010. User's handbook on Solar Water Heaters by United Nations Development Program.

Weil, R.L., Maher, M. (Eds.), 2005. Handbook of cost management, Second. ed. Wiley, Hoboken, N.J.

$\mathrm{Xu}, \mathrm{T}$., Flapper, J., 2009. Energy use and implications for efficiency strategies in global fluid-milk processing industry. Energy Policy 37, 5334-5341. doi:10.1016/j.enpol.2009.07.056 